\title{
Observations on Patella vulgata. Part II. Rate of Growth of Shell.
}

\author{
By
}

\author{
J. H. Orton, D.Sc.
}

Chief Naturalist at the Plymouth Laboratory.

\section{CONTENTS.}

Introduction

Pervations on rate of growth of Patella vilgata $\quad .864$

Patella spat on an experimental raft . . . . . . . . $\quad .870$

Seasonal shell-growth . . . . . . . . . . . . . . . . . 871

Variations in shell-shape and their primary cause . . . . . . . 873

Summary . . . . . . . . . . . . . . . . 874

\section{INTRODUCTION.}

Observations on the rate of growth of Patella vulgata have been made over an extended period and are herein collected together. A preliminary notice of some of the results was recorded in the Journal M.B.A., X, p. 319, 1914.

During the course of the building of a new wharf at the Great Western Railway Docks at Plymouth valuable experimental material was obtained gratuitously for general observation on the rate of growth of marine animals. This wharf (referred to later by the abbreviation G.W.W.) was rebuilt in 1911 and 1912 of reinforced cement and is 832 feet long by $60 \mathrm{ft}$. wide. It was built out into deep water (18 to $24 \mathrm{ft}$. at low water ordinary springs) to allow cargo vessels to unload alongside, and was erected on a foundation of 269 concrete piles driven into the sea-bottom. The upper ends of the piles were left with about $3 \mathrm{ft}$. projecting out of the water at L.W. ordinary springs. On the tops of these piles horizontal cement walings were first laid down in situ in the form of squares with horizontal and diagonal struts, and later vertical cement piles with diagonal struts were added upon these. The course of the construction was observed in frequent visits to the wharf, and by the courtesy of the Great Western Railway officials, especially Mr. J. A. Denny, the Assistant Divisional Engineer, and the works manager, Mr. Curtis, I was able to obtain detailed records of the dates of completion of construction of every pile or waling of which the structure is composed. 
Every portion of this wharf, therefore, provided experimental material for determining the maximum age of any marine organisms which might grow thereon after being exposed to the sea. It happened that the year 1911 was an unusually warm one, and unusually favourable for the growth of marine organisms, and the first nine months of the year 1912 were also warmer than the average, so that the growths obtained at this wharf were remarkable. It was soon found that many of the prevalent marine animals attained sexual maturity or full size at an age of only a few months to a few years, so that new generations soon began to overlap the earlier ones. Therefore it became a matter of much importance to define the breeding periods of the different animals obtained in order to evaluate the material collected. The outbreak of the war in 1914 occurred at a critical stage in this work, and postponed publication of many of the results.

\section{Observations on the Rate of Growth of Patella vulgata,}

During 1912 it was found that limpets settled chiefly on the vertical cement piles, and also on the horizontal ones, but rarely on the cement piles which were driven into the sea bottom and remained projecting about $3 \mathrm{ft}$. above L.W. ordinary springs, that is, to the level just below L.W. neaps. In a zone $4 \mathrm{ft}$. above the horizontal walings limpets were common, but rare at heights of 5 to 6 feet, i.e. above the level of H.W. neap tides; they therefore occurred mainly in a zone 3 to $12 \mathrm{ft}$. above lowwater ordinary spring tides, that is, between L. and H.W. neap tide levels. Early in 1913 collections of Patella were made from various parts of the wharf, and in addition a number of limpets were marked and observations begun on the rate of growth of individuals. Additional material was collected during the year and in 1914. The results of the work are shown in Tables I and II, p. 868 and 870, and in Figs. 1 and 2, p. 866 and 871. In Fig. 1 are plotted the dates at which the cement surfaces (on which limpets were found) were exposed to the sea against the lengths of the limpets at the time of collection or observation. The resulting graphs give the maximum growth-period, but indicate by their angle of slope only the minimum average rate of growth, since larvæ would not actually settle in many cases at the moment the cement was exposed to the sea.

Within a small area the cement walings were constructed at about the same time, so that if far greater latitude of movement be allowed to Patella than is known to occur, the maximum age as determined would not err by more than 2 or 3 weeks if it be assumed that limpets crawled from one part of the wharf to another. The growth of three marked individuals was measured at intervals, mostly of a fortnight, from January 27 to September 1, 1913, and is plotted in Fig. 2, p. 871, as well as by the thicker lines in Fig. 1, p. 866. 
The observed rate of growth in the period January to September, 1913, is greater than is indicated by most of the graphs in Fig. 1, i.e. where growth is plotted against the maximum possible period of growth, in spite of the arrest of growth shown in July (see Fig. 2) and the slower growth in February and March. Such a result is, however, to be expected from the fact that the breeding period of Patella at Plymouth extends from August to March, and that spat would only fall over a period from September-October to April-May with a maximum spat fall in the spring (see Journ. M.B.A., XV, 3, p. 857). The settlement of young Patella may therefore be expected to occur from September to May, hence the group of individuals shown at A and B in Fig. 1 are unquestionably limpets derived from early and late-falls of spat in the spatting season of 1911-1912. Similarly the groups of records at C and D in Fig. 1 are with little doubt derived from the spatfall of the season 1912-1913. The dotted lines ending at $\mathrm{C}$ in Fig. 1 are records of spatfalls whose growth was noted in 1913 (see Table I, Nos. 11 to 19). A few spat obtained on new structures built in the Cattewater in May, 1919, are shown in Fig. 1 as occurring in 1914 for convenience.

These observations show that at the G.W.W., Plymouth, Patella vulgata attained a length of at least $30 \mathrm{~mm}$. (see Fig. 1A) in the season 1911-1912 at an age of about one year (reckoning from Sept. to Sept.), and a length of $53 \mathrm{~mm}$. (see Fig. 1A) at an age of not more than two years in the period reckoning from September, 1911, to September, 1913. In December, 1913, the spat of the season, 1912-1913, ranged in size from 11 to $26 \mathrm{~mm}$. (see Fig. 1c) and grew to $37-41 \mathrm{~mm}$. by May, 1914, and 47-49 mm. by September, 1914 (see Fig. 1D). It is important, however, to remember that 1911 was an unusually warm season and that 1912 was warmer than the average during the first nine months of the year. Most of the situations from which Patella were obtained at the G.W.W. were damp and in the shade, and at about half-tide level. All these circumstances are favourable for rapid growth of shell and for increase in length of shell at the expense of height, as will be shown in Part III of the " Observations on Patella." For these reasons I conclude that the growth-rate in length shown by these limpets is high, and that a much lower average rate will occur on the adjacent rocks and reefs in Plymouth Sound. In 1919-1920 10 limpets were measured in situ at the G.W.W. (see Table III, p. 872) from July to May, and show a slower growth-rate than in 1911-1912. It was found that small individuals (A and B) grew continuously, though more slowly in September and January than in the remainder of the period. Among larger individuals, i.e. above lengths of $23.0 \mathrm{~mm}$., growth slackened only at the end of August and did not begin again until after February. The number of individuals observed is however small, and the results obtained can only be regarded as indicating the general phenomena of growth. 


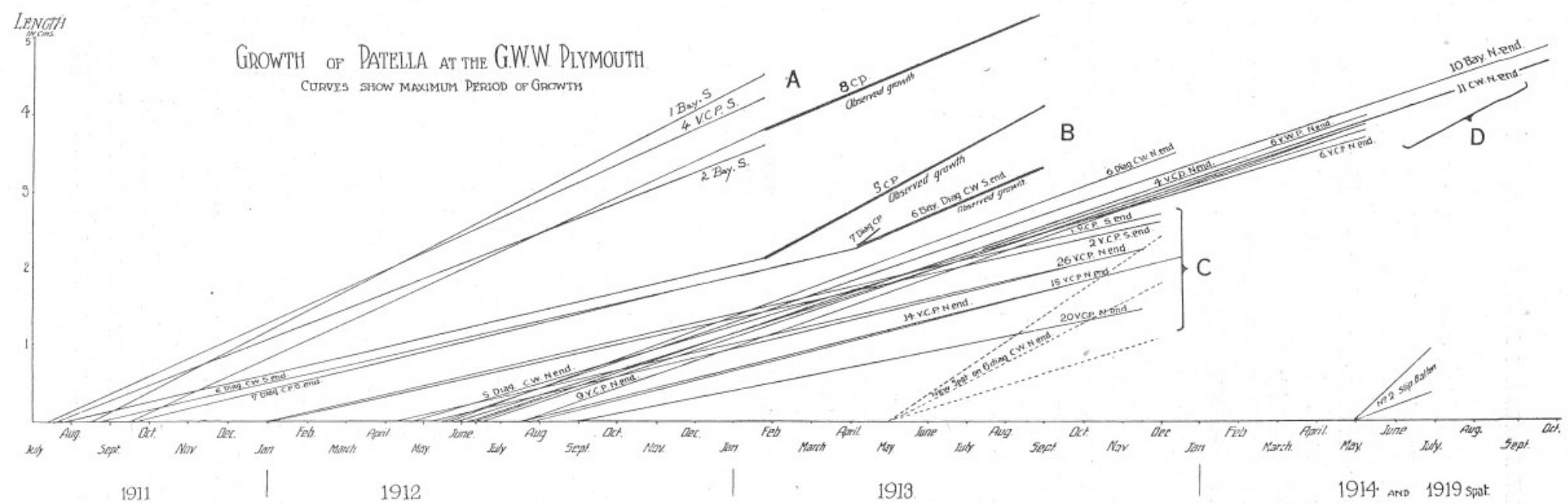

Fig. 1.-Graphic Representation of Observations on the Rate of Growth of Patella velgata Below High-Water Neaps at the Great Western Ramliy Wharf, Plymouth.

The length of the shell at the date of collection or observation is plotted against the date of completion of the structure on which the limpets were found. Thus each graph gives the maximum period of growth, and shows by its slope the minimum mean rate of growth. The thickened lines show the mean rate of growth given by the field observations shown in Table II, p. 870 . 
In Table I, p. 868, details are given of the greatest possible age of the limpets collected at the G.W.W., and also the probable mean age at the sizes given.

Since spat may fall at any time between September and May, the mean date of the fall of spat may be fixed in January. Field observations in 1913, 1914, and 1919 indicated that the main spatfall occurred about April-May. So that the mean period of growth and probable mean age given in Table $\mathrm{I}$ is regarded as likely to be too great in most cases. There is undoubtedly great variation in the size (length) of spat as a result of the drawn-out spawning season - apart from other considerations affecting size - so that it is impossible to dogmatise on the age of any limpet to within a few months. In Scottish limpets Russell (loc. cit., 1909) estimates the lengths at one year old as 20 to $25 \mathrm{~mm}$., at two years $38 \mathrm{~mm}$., about 43 in the third, and $45-48$ at the end of the fourth year, whereas it has been shown above that at Plymouth a length of $53 \mathrm{~mm}$. was attained at age certainly not more than two years. Moreover, a glance at A, Fig. 1, p. 866, will show that some limpets spatted in 1911 would in all probability have attained lengths of up to $60 \mathrm{~mm}$.- - from the trend of observed and plotted rate of growth - at an age of only two years.

The observations in Scotland and at Plymouth may be compared as follows :-

\begin{tabular}{|c|c|c|c|c|c|}
\hline & \multicolumn{4}{|c|}{ Lengths in mm. at } \\
\hline & & 1 year. & 2 years. & 3 years. & 4 years \\
\hline Scotland, & 1908 & $20-25$ & 38 & 43 & $45-48$ \\
\hline Plymouth & 1912 & $26-35$ & 53 & - & - \\
\hline, & 1913 & $11-27$ & $47-49$ & - & \\
\hline
\end{tabular}

These considerations show in the first place that the limpets spatted at Plymouth in 1911-1912 must be regarded as showing exceptional growth in length, and show in the second place that all the factors regarding shells should be known in order to compare samples from different localities or seasons. It will be shown in a later communication that the relations of length and breadth of the shells given in Table I are similar to those of most limpets growing between H. and L.W. neaps, but the heights and thicknesses are apparently a little less than usual in midtide limpets.

An illustration of the variation in the rate of growth of shell in different habitats is afforded by continuous records (see Table IV, p. 872) made on 11 marked shells in situ on the rocks in the lower barnacle zone below the Hoe, Plymouth, from July, 1919, to August, 1920. The limpets were all about one inch long and were attached to a rock facing south, and exposed to sun during spring tides. Seven of the shells showed very slight or no growth, and of the others the maximum increase in length was $3.4 \mathrm{~mm}$., and the average $2.6 \mathrm{~mm}$.; while the average increase in length of all the 
Records of Rate of Growth* of Patella vUlgata at the Great Western Ratlway Wharf, Mullbay Docks, Plymouth.

$(\mathrm{V} .=$ vertical $; \mathrm{H} .=$ horizontal ; C.P. $=$ cement pile ; C.W. $=$ cement waling ; W.P. $=$ wooden pile ; S. $=$ south ; N. =north ;

\begin{tabular}{|c|c|c|c|c|c|c|c|c|c|}
\hline & & & & & & & & & \\
\hline $\begin{array}{l}\text { No. of } \\
\text { observ } \\
\text { tions. }\end{array}$ & $\begin{array}{cc}\mathrm{f} & \begin{array}{c}\text { Site of } \\
\text { observa- } \\
\text { ta- }\end{array} \\
\text { tion. }\end{array}$ & $\begin{array}{c}\text { No. of } \\
\text { indi- } \\
\text { viduals. }\end{array}$ & $\begin{array}{l}\text { Maximum } \\
\text { period of } \\
\text { growth. }\end{array}$ & $\begin{array}{c}\text { Greatest } \\
\text { possible as } \\
\text { to neares } \\
\text { calendar } \\
\text { month. }\end{array}$ & $\begin{array}{l}\text { Probable mean } \\
\text { period of } \\
\text { growth. }\end{array}$ & $\begin{array}{l}\text { Probable } \\
\text { mean age } \\
\text { to nearest } \\
\text { calendar } \\
\text { month. }\end{array}$ & $\begin{array}{l}\text { Max } \\
\text { size i } \\
\text { Lengt } \\
\text { Bread }\end{array}$ & $\begin{array}{l}\text { mum } \\
\text { mm. } \\
\text { (l) } \times \\
\text { h (b) }\end{array}$ & $\begin{array}{c}\text { Remarks } \dagger \\
\text { Measurements in mm. }\end{array}$ \\
\hline & & & $1911 \quad 1913$ & & & & & & \\
\hline 1 & 1 Inner Bay, S. & 6 & Sept. 9-Jan. 7 & 17 & Jan., 1912-Jan., 1913 & 13 & $46 \cdot 5$ & $38 \cdot 0$ & $\mathrm{~h}=12.5 \mathrm{~mm}$ \\
\hline 2 & 4 V.C.P., S. & 1 & July 13-Jan. 25 & 20 & $, \quad, \quad$, & 13 & $43 \cdot 0$ & $35 \cdot 0$ & $\mathrm{~h}=16.0$; ripe female $\ddagger$ \\
\hline 3 & 2 Bay, S. & 3 & July $15-J a n .28$ & 20 & , & 13 & $37 \cdot 0$ & $31 \cdot 0$ & ripe male* \\
\hline 4 & 1 Outer Bay, S. & 5 & Aug. 12-Jan. 25 & $18 \cdot 5$ &,$\quad \quad$, & 13 & $46 \cdot 0$ & $39 \cdot 0$ & $\mathrm{~h}=14.5 ; 2$ ripe,+ 1 ripe $\S \hat{\sigma}$. \\
\hline 5 & 5 C.P., S. & 1 & July 22-Jan. 27 & 20 & May, 1912-Jan., 1913 & 8 & $21 \cdot 0$ & $16 \cdot 0$ & \\
\hline 6 & , & 1 & 27.1.13-2.9.13 & 27 & - & 15 & $41 \cdot 0$ & $33 \cdot 0$ & observed growth $=20 \mathrm{~mm}$., see Fig. 2 . \\
\hline 7 & 8 C.P., S. & 1 & Sept. 16-Jan. 27 & $17 \cdot 5$ & Jan., 1912-Jan., 1913 & 13 & $38 \cdot 0$ & $32 \cdot 0$ & \\
\hline 8 & , & 1 & 27.1.13-2.9.13 & 25 & - & 20 & $53 \cdot 0$ & $45 \cdot 0$ & observed growth $=15 \mathrm{~mm}$., see Fig. 2. \\
\hline 9 & 6 Diag. C.W., S. & 1 & Sept. 16-April 4 & 20 & May, 1912-April, 1913 & 12 & $22 \cdot 5$ & $17 \cdot 0$ & \\
\hline 10 &, & 1 & 4.4.13-2.9.13 & 25 & - & 17 & $33 \cdot 0$ & $28 \cdot 5$ & observed growth $=10.5 \mathrm{~mm}$., see Fig. 2. \\
\hline 11 & 8 C.P., S. & 6 & Sept. 16-July 18 & - & Jan., 1913-July, 1913 & 3 to 6 & $14 \cdot 0$ & - & 1913 spat ; 9 to $14 \mathrm{~mm} . \|$ \\
\hline 12 & 6 V.C.P., S. & 9 & $\begin{array}{cc}\text { Aug. } & 19-S e p t .16 \\
1912 & 1913\end{array}$ & - & Jan., 1913-Sept., 1913 & 5 to 8 & $21 \cdot 0$ & - & , $\quad 12$ to $21 \mathrm{~mm} . \|$ \\
\hline 13 & 14 V.C.P., N. & 4 & July 12-Dec. 16 & - & Jan., 1913-Dec., 1913 & 9 to 12 & $21 \cdot 0$ & $16 \cdot 0$ & 10 to $21 \mathrm{~mm}$. \\
\hline 14 & 15 V.C.P., N. & 1 & July $27-\quad$, & - & ., & , & $21 \cdot 0$ & $15 \cdot 8$ & , \\
\hline 15 & 26 V.C.P., N. & 1 & May 4- ,, & - & , & , & $22 \cdot 0$ & $16 \cdot 0$ & , \\
\hline
\end{tabular}


1620 V.C.P., N.

1719 V.C.P., S.

1821 V.C.P., S.

196 Diag. C.W., N.

20 All parts

214 V.C.P., N.

225 Diag. C.W., N.

236 V.C.P., N.

2410 Bay C.W., N.

259 V.C.P., N.

266 V.W.P., N.

2710 Bay, N.

2811 Bay, N.

29 No. 2 Slip, Batten

30 No. 2 Sewer-pipe, Batten

31 Cawsand raft
2 Sept. 30-Dec. 16

Jan. 9- ,

Jan. 20- ,,

May 20-Dec. 12

1912

$\infty \quad$ - June 9

1 June 11- ,,

$6+10$ May 20- ,

$13+\infty$ June 21- ,

2 July 19- ,,

$3+\infty$ Aug. 17- ,

4 July 18 - ,

20 June 17-Oct. 23

35

$$
1919 \quad \text { }
$$

3 Oct.(1918) June 28 ca.6

1 May June 28

145 July 16 Oct. 1920
-. May, 1913-Dec., 1913

25 Jan., 1913-Dec., 1913

25

21

-

26 Jan., 1913-June, 1914

$26 \cdot 5$

$25 \cdot 5$

$24 \cdot 5$

$23 \cdot 5$

$24 \cdot 5$

30

30

2

$$
\text { , }
$$$$
,
$$

1913

9 to 12

9 to 12

19

3 to 6

18

18

18

18

18

18

22

22
$14.5 \quad 11.5 \quad 1913$ spat; 13.5 to $14.5 \mathrm{~mm}$.

$\begin{array}{ll}27 \cdot 0 & 20 \cdot 8\end{array}$

,, from $11 \times 8.8$.

, from $24.8 \times 17 \cdot 6$.

also six 1913 spat, 11 to $24 \mathrm{~mm}$.

$\infty 1914$, spat up to ca. $10 \mathrm{~mm}$.

$40 \cdot 0 \quad 33 \cdot 5$

$37 \cdot 0 \quad-$

5 others 34 to 37 , and 101914 spat to $10 \mathrm{~mm}$.

12 others 30 to 38 , and 1914 spat to $10 \mathrm{~mm}$.

$41 \cdot 0 \quad 34 \cdot 0$ and one $36 \times 29 \mathrm{~mm}$.

$39 \cdot 0 \quad 34 \cdot 0$ and 32 and 38 ; and oo 1914 spat to $10 \mathrm{~mm}$.

$39 \cdot 0 \quad 32 \cdot 0$ also $38 \times 31,32 \times 26$, and $30 \times 25 \mathrm{~mm}$.

$49 \cdot 0 \quad 46 \cdot 0$

$47 \cdot 0 \quad-$

Jan., 1919-June, $1919 \quad 2$ to 6

$9 \cdot 2$ - 1919 spat, 7 to $9 \cdot 2 \mathrm{~mm}$.

$2 \quad 3 \cdot 6 \quad$ a 1919 spat.

is to $10 \quad 13.0 \quad-\quad 1920$ spat.

* The records of growth are for limpets growing mainly between H. and L W. neaps. The shells are mostly thin and of the low-water type, i.e. flat and broad with length, breadth, and height relationships closely similar to those of the Looe Island mid-tide or low-water limpets, to be described in Part III of the "Observations on Patella,"

$\dagger$ Unless otherwise noted the measurements refer to lengths in $\mathrm{mm}$.

Successful artficial fertilisations were made from these ripe individuals.

$\$$ An artificial fertilisation of these individuals gave $10 \%$ segmenting eggs and, later, trochospheres.

II Spat ranging in length from a few to $10 \mathrm{~mm}$. were observed in June in 1913, 1914, and especially in 1919, when they were found at the G.W.W., rocks below Plymouth Hoe, and Looe Island. 
eleven shells for the whole period was only $1.3 \mathrm{~mm}$., and less than $1 \mathrm{~mm}$. for the period July to March in which all survived.

An arrest in shell-growth at lengths of about $25 \mathrm{~mm}$. was observed by Russell (Proc. Zool. Soc., 1909, p. 247), and two instances occur in Table III (D and E). It has been noted that a change in sex-proportion (see Journ. M.B.A., XV, 3, p. 854) begins to show in populations of Patella at about this size, and it is highly probable that the observed arrest in growth is accompanied by profound changes in the gonad.

\section{TABLE II}

Rate of Growth of Three Marked Patella vulaata, Measured* in situ at the Great Western Railway Wharf, Plymouth (SEE Fig. 2, p. 871.)

(For explanation of symbols see Table I, p. 868.)

\begin{tabular}{lcccccc} 
"Home " & \multicolumn{2}{c}{5 C.P., S. } & \multicolumn{2}{c}{8 C.P., S. } & \multicolumn{2}{c}{ D Diag. C.W., S. } \\
$\quad$ 1913 & L & B & L & B & L & B \\
Jan. 27 & $21 \cdot 0$ & $16 \cdot 0$ & $38 \cdot 0$ & $32 \cdot 0$ & - & - \\
Feb. 21 & $23 \cdot 0$ & $18 \cdot 0$ & $39 \cdot 0$ & $33 \cdot 0$ & - & - \\
March 12 & $24 \cdot 5$ & $20 \cdot 0$ & $40 \cdot 0$ & $33 \cdot 5$ & - & - \\
April 4 & $26 \cdot 5$ & $21 \cdot 5$ & $42 \cdot 0$ & $35 \cdot 0$ & $22 \cdot 5$ & $17 \cdot 0$ \\
$\quad$ ", 23 & $29 \cdot 0$ & $23 \cdot 5$ & $43 \cdot 5$ & $37 \cdot 5$ & $25 \cdot 0$ & $19 \cdot 0$ \\
May 23 & $32 \cdot 5$ & $26 \cdot 5$ & $44 \cdot 5$ & $39 \cdot 0$ & $27 \cdot 5$ & $22 \cdot 5$ \\
June 20 & $36 \cdot 0$ & $28 \cdot 0$ & $48 \cdot 5$ & $42 \cdot 0$ & $31 \cdot 5$ & $25 \cdot 5$ \\
July 4 & $38 \cdot 0$ & $30 \cdot 0$ & $50 \cdot 0$ & $43 \cdot 0$ & $32 \cdot 0$ & $25 \cdot 0$ \\
", 18 & $37 \cdot 0$ & $31 \cdot 0$ & $51 \cdot 0$ & $43 \cdot 0$ & ..m. & - \\
Aug. 8 & $38 \cdot 0$ & $31 \cdot 5$ & $51 \cdot 5$ & $44 \cdot 0$ & $32 \cdot 0$ & $26 \cdot 5$ \\
Sept. 2 & $41 \cdot 0$ & $33 \cdot 0$ & $53 \cdot 0$ & $45 \cdot 0$ & $33 \cdot 0$ & $28 \cdot 5$ \\
", 16 & \multicolumn{2}{c}{ lost } & \multicolumn{2}{c}{ lost } & $33 \cdot 5$ & $27 \cdot 0$
\end{tabular}

The shells of these limpets were impregnated by the calcareous lichen Arthropyrenia foveolata, as are most Patella and Balanus in this and similar localities, but it seems unlikely that either this or the marking of the shells with a file, and later with anti-fouling paint (which dries rapidly in the sun) can have contributed to more than a fraction, if any, of the observed arrest of growth.

\section{Patella Spat on an Experimental Raft.}

On July 16, 1919, a large wooden raft $(20 \times 6 \times 2 \mathrm{ft}$. $)$ was moored in Cawsand Bay for the purpose of carrying out general experiments on rate

\footnotetext{
* Measured to the nearest $0.5 \mathrm{~mm}$. : errors of $1 \mathrm{~mm}$. may occur by measuring the axis slightly obliquely; see also Tables III and IV.
} 
of growth. On October 9, 1920, a large spatfall of 145 Patella was found on the surface of the raft, which was awash and covered with Enteromorpha. At this time the spat ranged in size (length) from 8 to $13 \mathrm{~mm}$., and were therefore similar in size to the 1913 spat at the G.W.W. (see Fig. 1, p. 866). The raft was unfortunately destroyed in a gale late in December in the same year, and the lid on which the Patella were attached was lost. It had been hoped to determine the sex in all these individuals, which were known with certainty to have been spatted in the 1919-1920 season and were probably not more than 5 months old.

\section{Seasonal Shell-growth.}

The observations on seasonal shell-growth herein recorded are incomplete, and are to be regarded as preliminary investigations. It is now known that in order to establish satisfactorily the facts with regard to

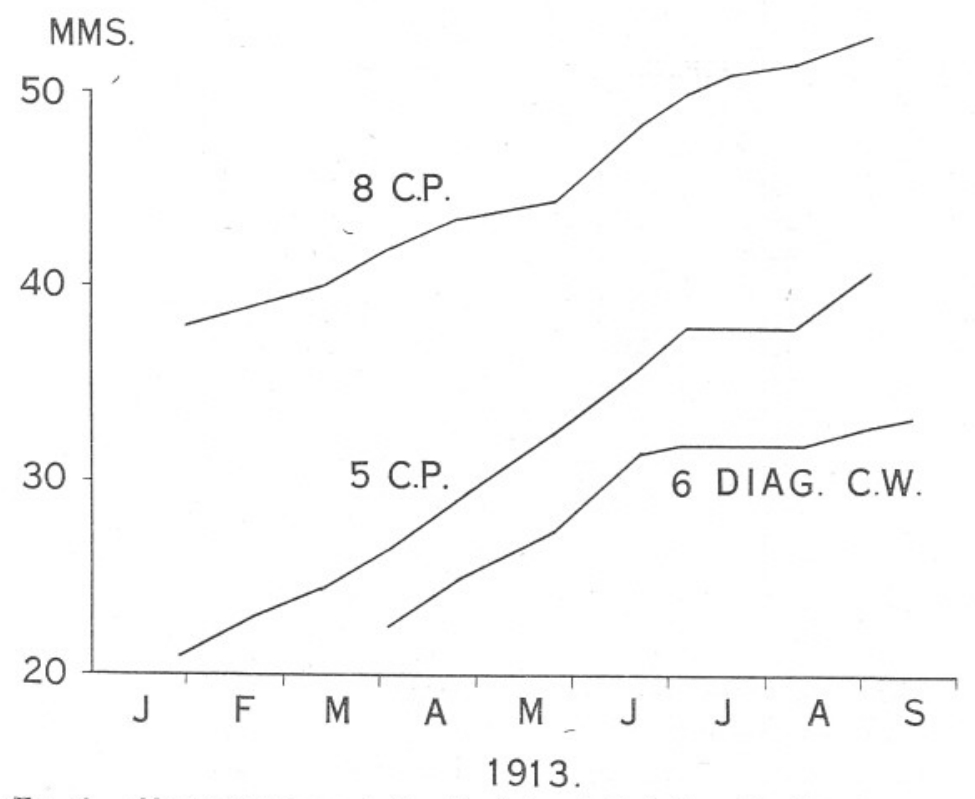

Fic 2.-Observed increase in length of the shell of three Patella vulgata at the Great Western Railway Wharf, Plymouth (see Table II, p. 870) showing an arrest of growth at mid summer; from measurements made at intervals of 2 or 4 weeks (Habitat : below H.W. neaps).

seasonal shell-growth, it is desirable to study the material in the field and laboratory fortnightly or monthly during several successive years in different localities.

Shell-growth in young individuals, up to a length of about $25 \mathrm{~mm}$., appears to be almost continuous in the Plymouth district with a tendency 
TABLE III.

Rate of Growth of some Patella vulgata which were Marked and Measured $\dagger$ in situ at the G.W.W. IN 1919-1920. ( $\mathrm{L}=$ length ; $\mathrm{B}=$ breadth of shell.)

\begin{tabular}{|c|c|c|c|c|c|c|c|c|c|c|c|c|c|c|c|}
\hline \multicolumn{3}{|c|}{ Individual } & \multicolumn{2}{|c|}{ A. } & \multicolumn{2}{|c|}{ B } & $\mathrm{C}$ & D & $\mathrm{E}$ & $\mathrm{F}$ & G. & H. & \multicolumn{3}{|c|}{ J. } \\
\hline Site of " & & & 7 V.C & P., S. & $2 \mathrm{D} . \mathrm{C}$ & C.W., s & 7 V.C.P., S. & 2 V.C.P., S. & 1 V.C.W., S & 1 R.4P., S. & 7 V.C.P., S. & 8 C.P., S. & 1 V.C.P., S. & $11 \mathrm{~V} . \mathrm{C}$ & $\begin{array}{c}\text { C.P., S } \\
\text { B. }\end{array}$ \\
\hline $19-1920$ & & & L. & B. & L. & B. & L. B. & L. B. & L. B. & L. B. & L. B. & L. B. & L. & L. & $\begin{array}{c}\text { B. } \\
31.5\end{array}$ \\
\hline 1 & . & . & $11 \cdot 0$ & $8 \cdot 0$ & $13 \cdot 0$ & $9 \cdot 5$ & $23.5 \quad 18 \cdot 0$ & $24 \cdot 0 \quad 19 \cdot 0$ & $24 \cdot 0 \quad 20 \cdot 0$ & $26 \cdot 0 \quad 20 \cdot 0$ & $28 \cdot 5 \quad 23 \cdot 0$ & - & $33 \cdot 0$ & $37 \cdot 0$ & \\
\hline 25 & . & . & $13 \cdot 0$ & $9 \cdot 0$ & $16 \cdot 0$ & $12 \cdot 0$ & $23 \cdot 0 \quad 19 \cdot 0$ & $26 \cdot 0 \quad 21 \cdot 0$ & $24 \cdot 5 \quad 21 \cdot 0$ & $29 \cdot 0 \quad 22 \cdot 5$ & $30 \cdot 5 \quad 24 \cdot 0$ & - & $33 \cdot 5$ & $38 \cdot 0$ & $31 \cdot 5$ \\
\hline Increa & se & . & $2 \cdot 0$ & $1 \cdot 0$ & 3.0 & $2 \cdot 5$ & nil $1 \cdot 0$ & $2 \cdot 0$ & $0.5 \quad 1.0$ & $3.0 \quad 2.5$ & $2.0 \quad 1.0$ & - & 0.5 & $1 \cdot 0$ & nil \\
\hline g. $25^{*}$ & . & . & $15 \cdot 0$ & $11 \cdot 0$ & $17 \cdot 2$ & $14 \cdot 0$ & $26 \cdot 0 \quad 21 \cdot 0$ & $27 \cdot 0 \quad 21 \cdot 5$ & $25 \cdot 0 \quad 21 \cdot 5$ & $31.5 \quad 24.5$ & $32 \cdot 0 \quad 25 \cdot 5$ & - & $35 \cdot 5$ & $39 \cdot 4$ & $32 \cdot 8$ \\
\hline Ine & se & . & $2 \cdot 0$ & $2 \cdot 0$ & $1 \cdot 2$ & $2 \cdot 0$ & $2.5 \quad 3.0$ & nil nil & $0.5 \quad 0.5$ & $2.5 \quad 2.0$ & $1.5 \quad 1.5$ & - & 1.5 & $1 \cdot 0$ & 0.5 \\
\hline ot. $25^{*}$ & . & . & $16 \cdot 0$ & $12 \cdot 0$ & $18 \cdot 4$ & $14 \cdot 2$ & lost & $26.4 \quad 21 \cdot 4$ & $25 \cdot 2 \quad 22 \cdot 6$ & lost & lost & $28 \cdot 0 \quad 23 \cdot 4$ & $34 \cdot 8$ & $39 \cdot 0$ & $32 \cdot 0$ \\
\hline Increa & se & . & $1 \cdot 0$ & $1 \cdot 0$ & $1 \cdot 2$ & nil & - & nil nil & nil $0 ! 5$ & - & - & $-\quad-$ & nil & nil & nil \\
\hline t. $29^{*}$ & . & . & $18 \cdot 4$ & $14 \cdot 0$ & & ost & - & $26 \cdot 6 \quad 22 \cdot 0$ & $25 \cdot 8 \quad 22 \cdot 6$ & - & - & $28 \cdot 6 \quad 24 \cdot 4$ & $35 \cdot 0$ & $39 \cdot 4$ & $32 \cdot 2$ \\
\hline Increa & & . & $2 \cdot 4$ & $2 \cdot 0$ & & - & - & $0.5 \quad 1.0$ & $0.5 \mathrm{nil}$ & - & - & $0.6 \quad 1.0$ & nil & nil & nil \\
\hline c. 12 & . & . & $20 \cdot 6$ & $15 \cdot 6$ & & - & - & lost & $26 \cdot 2 \quad 22 \cdot 0$ & 一 & - & $28 \cdot 6 \quad 24 \cdot 4$ & $35 \cdot 4$ & $39 \cdot 4$ & $32 \cdot 0$ \\
\hline Incre & & . & $2 \cdot 2$ & $1 \cdot 6$ & & - & - & - & $0 \cdot \overline{0} \quad$ nil & - & - & nil nil & nil & nil & nil \\
\hline b. 7 & . & . & $21 \cdot 5$ & $17 \cdot 0$ & & - & - & - & lost & - & - & lost & $35 \cdot 0$ & $39 \cdot 2$ & $32 \cdot 5$ \\
\hline Incr & se & . & 0.9 & $1 \cdot 4$ & & - & - & - & - & - & - & - & nil & nil & $0 \cdot 5$ \\
\hline у 4 & . & . & lo & st & & - & - & - & - & - & - & - & lost & $39 \cdot 5$ & $33 \cdot 0$ \\
\hline
\end{tabular}

\section{TABLE IV.}

Measurements $\dagger$ in situ of Marked Patella vulgata on the Needles, the Hoe, Plymouth, $1919,1920$.

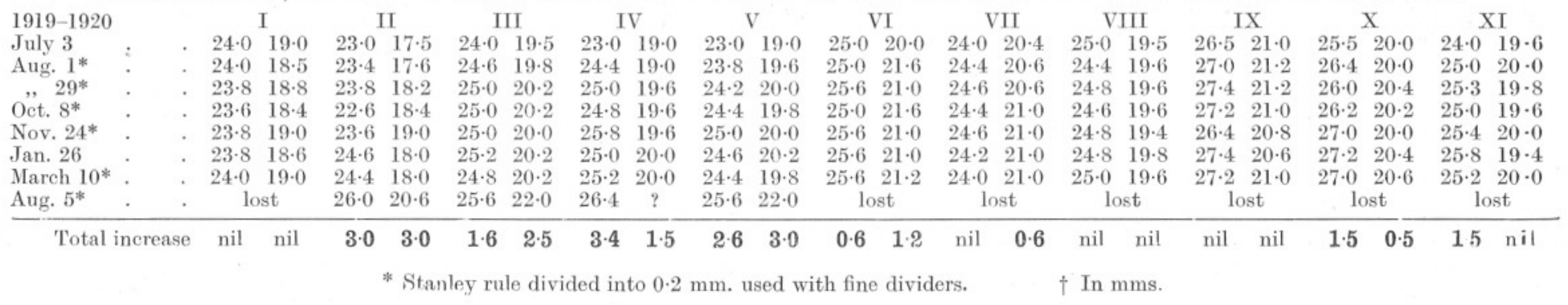


to slower growth at midsummer and in midwinter (see Tables II and III). At lengths of about $25 \mathrm{~mm}$. there is an indication of an arrest of growth in some individuals - apart from seasonal arrest of growth (see Table IV and Table III, C, D, and E). Above lengths of about $30 \mathrm{~mm}$. the growthperiod becomes more sharply defined into at least a definite post-breeding spring and early summer phase followed apparently by a resting midsummer period (see Fig. 2, p. 871), after which growth may or may not occur (see Tables II and III). The extent of the midsummer arrest of growth shown in Fig. 2 is not known, and remains to be investigated. The possibility of two shell-growing periods is indicated, and the problem presented is of importance in interpreting the growth-rings on the shells from any particular locality.

Definite investigations on general seasonal growth during a period of years combined with observations on sex and spawning are now desirable, with a view to defining the relation between breeding and shell-growth on the one hand and the relation of environmental (i.e. habitat and climatic) conditions to both breeding and shell-growth on the other hand.

\section{Variations in Shell-Shape and their Primary Cause.}

In the course of studies on Patella vulgata particular attention has been given to the variations in shell-shape, especially shell-height, and the cause of the variations exhibited. The results of this portion of the work will be given later in Part III of the observations, in which it will be shown that limpets which are covered at neap tides have shells whose dimensions are given by the statement $\frac{\mathrm{L}+\mathrm{B}}{2(\mathrm{H})}=2.55$ to $2 \cdot 81$, for lengths above $35 \mathrm{~mm}$. of about 1000 individuals from different localities; and that limpets occurring above high-water neaps grow shells whose dimensions are given by $\frac{\mathrm{L}+\mathrm{B}}{2(\mathrm{H})}=1.81$ to 2.25 (about 1000 individuals from different localities); where $\mathrm{L}=$ length, $\mathrm{B}=$ breadth, and $\mathrm{H}=$ height of shell. Among high-water shells the lower value for $\frac{\mathrm{L}+\mathrm{B} \text {, }}{2(\mathrm{H})}$ namely $1 \cdot 81$, is given by limpets in dry situations, and the high value by those in damp situations. These facts-along with certain observations-lead to the conclusion that the height of the shell in Patella vulgata is governed almost entirely by the sum of the factors which tend to cause the animals to dry up (the desiccation factor), and that therefore wave-action plays only a minor and secondary part in controlling shell-height.

The variations in shell-shape shown by limpets in different habitats is an important matter in relation to studies on rate of growth, and must necessarily be considered in such work. 


\section{SUMMARY.}

Many common limpets, Patella vulgata, settled and grew on the cement piles of a new wharf constructed at Plymouth. Each pile or part of this wharf provided experimental material for the determination of the maximum age of the limpets which grew thereon, as the dates of completion were known. It was found that at an age of about one year limpets grew to lengths of 26 to $35 \mathrm{~mm}$. in 1912, and to at least 11 to $27 \mathrm{~mm}$. in 1913 : and at an age of two years to at least $53 \mathrm{~mm}$. in 1911-1913, and to $47-49 \mathrm{~mm}$. in 1912-1914.

The shells were of the mid-tide-level type, and were low, broad, and rather thin. It is considered that such growth in length is unusual, and is correlated with the habitat and favourable climatic conditions. In the same situation in 1913 marked limpets grew from January 27 to September 2 , respectively, $20 \mathrm{~mm}$. (from 21 to 41 ) and $15 \mathrm{~mm}$. (from 38 to 53), and showed arrest of growth in midsummer.

Other marked limpets showed arrest of growth in the winter period, and many at lengths of about $25 \mathrm{~mm}$. an arrest of growth independent of any season of growth. Seasonal shell-growth is discussed briefly ; a postbreeding shell-growing period is general in spring and early summer, but it is not known whether a midsummer resting-period is general among individuals more than one year old. Ad hoc investigations are suggested in combination with work on sex and spawning.

A preliminary notice is given of investigations into the cause of variation in shell-height, wherein it is shown that shell-height is determined probably entirely by the degree of exposure of limpets to desiccation, in such a manner that the drier the habitat the higher the shell is. Limpets submerged at neap tides have a relatively uniformly low shell, those exposed at high-water neaps have a relatively high shell, which is higher in the drier than in the damper situations, apparently irrespective of exposure to wave-action. 